\title{
The Relationship Between the Ergonomic Situation of the Workstations and Musculoskeletal Disorders With the Quality of Work Life and Demographic Variables in the Administrative Staff of the Tehran Municipality
}

\author{
Pezhvak Ghasemzade $^{1}$, Shahnaz Tabatabaei ${ }^{2 *}$, Amir Kavousi², Mahnaz Sareme ${ }^{3}$
}

1. MSc in Ergonomics, Department of Safety and Environment, School of Health, Shahid Beheshti University of Medical Sciences, Tehran, Iran

2. Associate Professor, Department of Safety and Environment, School of Health, Shahid Beheshti University of Medical Sciences, Tehran, Iran

3. Assistant Professor, Department of Safety and Environment, School of Health, Shahid Beheshti University of Medical Sciences, Tehran, Iran

Article Info
Original Article
Received: 21 Feb 2017 ;
Accepted: 13 Jan. $2018 ;$
Published Online $2018 / 01 / 23$
DOI: $10.30699 /$ jergon.5.3.1
Use your device to scan
and read the article online

Corresponding Author Shahnaz Tabatabaei Associate Professor, Department of Safety and Environment, School of Health, Shahid Beheshti University of Medical Sciences, Tehran, Iran Tel: 09217730996

Email:

sh.tabatabaei@sbmu.ac.ir

\begin{abstract}
Background: Attention to the workstations of the employees and their quality of work life has become increasingly important due to the increased competition in the organizations. The present study aimed to investigate the relationship between the ergonomic situation of the workstations and musculoskeletal disorders with the quality of work life and demographic variables in the administrative staff of the Tehran Municipality.
\end{abstract}

Methods: The present study was a descriptive and analytical one. The statistical population included a total of 600 persons, working in one of the regions in the Tehran Municipality. Of the 600 staff, a total of 255 were selected as the available sample group. The instruments consisted of the questionnaires, including the individual and occupational information, the Nordic questionnaire, the Walton Quality of work life, and the checklist of the ergonomic indices of the working environment for the administrative staff. In order to analyze the data, Student's t-test and multiple regression analysis were used.

Results: In this study, the majority of the samples were females $(56.9 \%)$ with a mean age of 33 years. A significant positive relationship was observed between all the ergonomic indices and the quality of work life. Significant correlations among the parameters such as age, education, sleeping at night, psychological conditions, musculoskeletal disorders of the neck, shoulder, and foot were observed simultaneously with the quality of work life. The quality of work life of an employee could be predicted through the musculoskeletal disorders and demographic variables but could not be predicted by the ergonomic indicators.

Conclusion: In this study, a relationship existed between the ergonomic condition of the workstations and musculoskeletal disorders with the quality of work life and demographic variables. Therefore, the physical condition and the quality of the work life of the employees would be positively affected by the improvement of the ergonomic condition of the workstations.

Keywords: Workstations; Musculoskeletal Disorders; Quality of Work Life; Administrative Staff; Municipality

Copyright ( ) 2018, Journal of Ergonomics. This is an open-access article distributed under the terms of the Creative Commons Attribution-noncommercial 4.0 International License which permits copy and redistribute the material just in noncommercial usages, provided the original work is properly cited.

\section{How to Cite This Article:}

Ghasemzade P, Tabatabaei S, Kavousi A, Sareme M. The Relationship Between the Ergonomic Situation of the Workstations and Musculoskeletal Disorders With the Quality of Work Life And Demographic Variables in the Administrative Staff of the Tehran Municipality. J Ergon. 2018; 5 (3) :1-11 


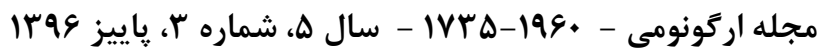

\author{
مقاله يثروهشى
}

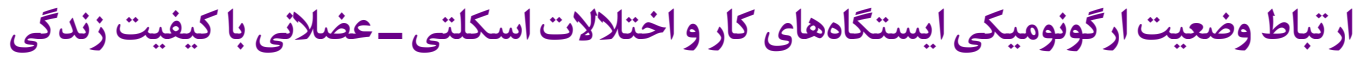

كارى و متغيرهاى دموكرافيكى در كاركنان ادارى شهردارى تهران

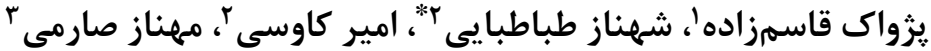

ا. دانشجوى كارشناسى ارشد ارگونومى، گروه ايمنى و محيطزيست، دانشكده سلامت، دانشگاه علوم بزشكى و خدمات بهداشتى و

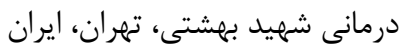

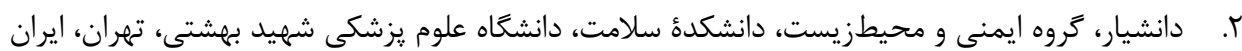

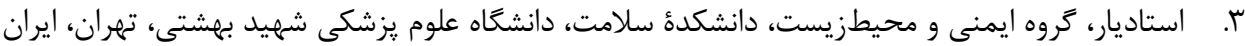

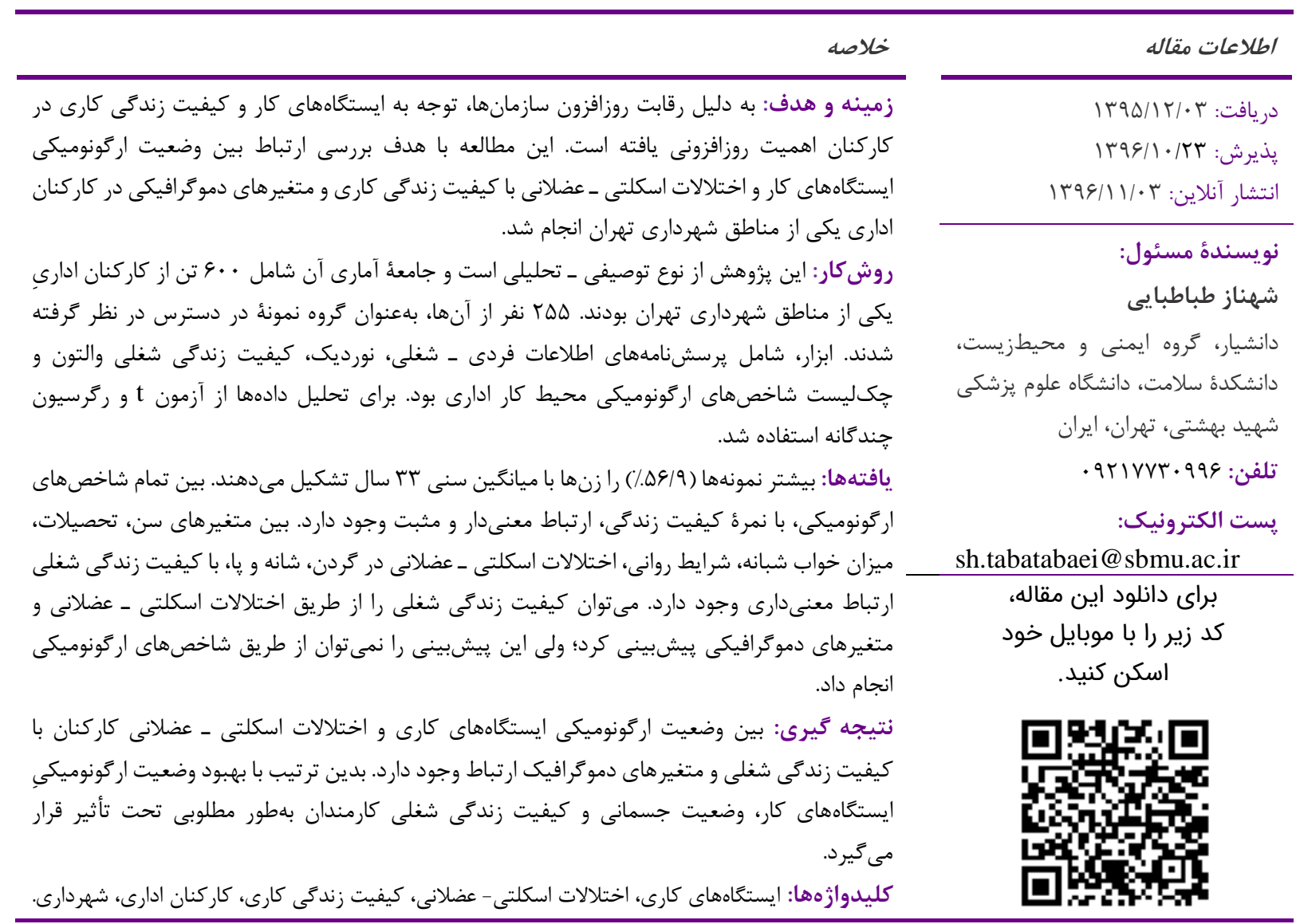

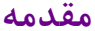

كاركنان محسوب مىشوند [1]]. ازاينرو، طراحى اركونوميكى ايستخاههاى كارى در محيطهاى ادارى اهميت بسزائى دارئ دارد.

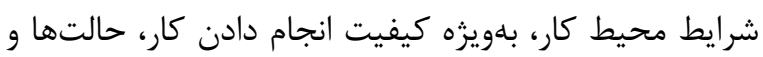
حركتهايى كه كارمند مجبور است براى انجام آن به بدن بهن خود بدهد، ممكن است به علت تكرار يا تجاوز از حد طبيعى، باعث ايجاد مشكلات و اختلالاتى براى فرد شود. ابزار و وسايل بل بله
امروزه، يروهشگَران به موضوعاتى كه موجب افزايش

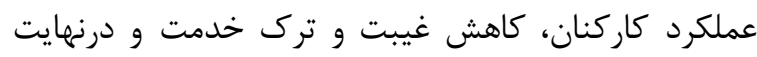
افزايش كيفيت زندكى شغلى (Quality of work life) آنها شود، توجه مى كنند و مى يردازند. وضعيت نامناسب بدن و ضعيف بودن طراحى ايستخاههاى كارى (Workstations) از نظر ارگونوميكى، ازجمله عوامل كاهنده كيفيت زندگى شغلى لئى 
معنى دارى در شدت درد در نواحى گردن، شانه، ساعد و مج

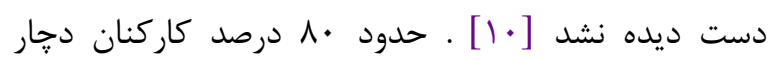

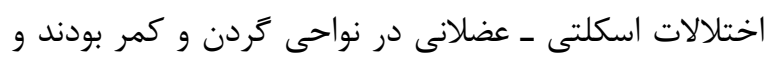
مقايسُٔ مطالعات نشان مىدهد كه بيشترين شيوع اختلالات

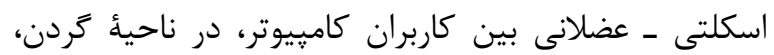
شانه، كمر و צشت است [11] كيفيت زندكى شغلى، با استرس شغلى و قصد ترك شغل، رابطة معنادارى دارد [YI]]. برخى از محققان دريافتند كه اختلالات اسكلتى عضلانى در با ماه كذشته در نواحى كمر و شانه به كيفيت زندگى شغلى مربوط است [111]. جنسيت

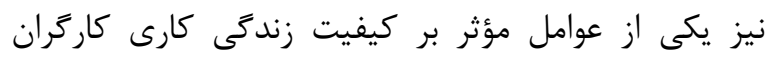
قراردادى اتحادية ارويا و كاركنان كارخانههاى كربنات سديم برئ

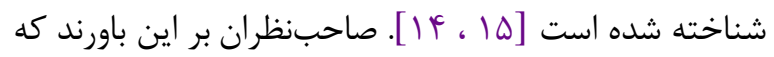
كيفيت زندگى كارى اثر مهمى بر واكنش كاركنان در زمينههايى جون هويت سازمانى، رضايت شغلى، مشاركت

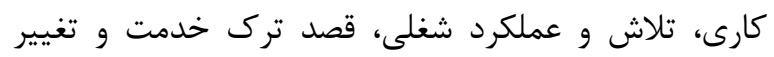
سازمانى دارد [91]]. شرايط جسمى و روانى كاركنان در ابتلاى آنها به دردهاى مزمن اسكلتى ـ عضلانى تأثير دارد و بهبود داني

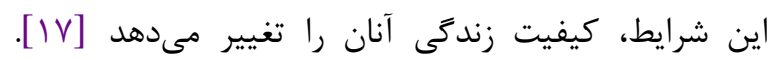
همبستخى مثبت و معنى دارى بين مؤلفههاى كيفيت زندگى ينى كارى و رضايت شغلى كاركنان يافت شد و متغير تعديل تحصيلات (بالاتر) تأثيرى كاهنده بر شدت رابطهُ بين دو متغير دارد [111]]. نيز رابطة معنادارى بين كيفيت زندكى كارى و و

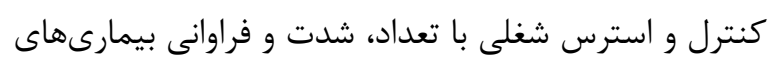
جسمى توسط محققان گزارش شد [19]. شيوع اختلالات اسكلتى ـ عضلانى در نواحى نشيمن، كردن و زانوى كارمندان نشان داد كه صندلى و موس كامييوتر بيشترين نقش را رادئ در

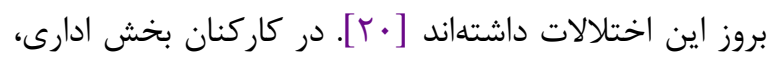
وجود ارتباطى معنى دار بين درد يشت با ميزان استفاده از

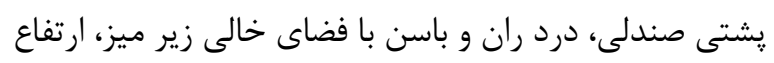

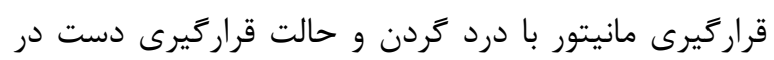

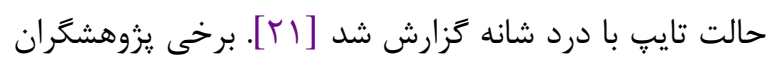
به نامناسب بودن وضعيت ارگونوميكى ايستخاههاى كارى و

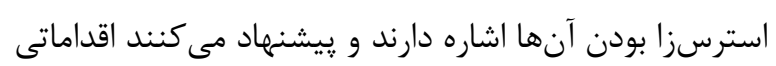
در راستاى كاهش ريسك براى ايستخاههاى كارى انجام بخيرد.

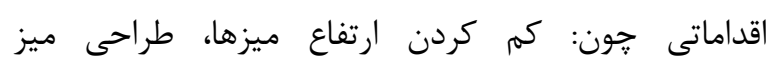

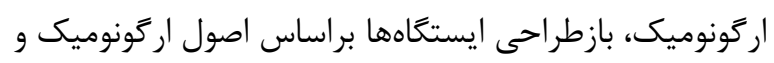

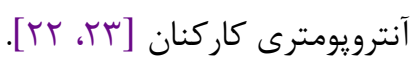

نامناسب، كمبود فضا، ناكافى بودن نور يا بازتاب آن، سايههاى

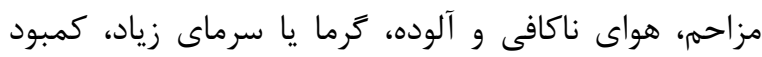
جريان هوا، سروصداى بيشازحد و زيانآور، استقرار خطرناى وسايل و مواد، سبب ايجاد بيمارىهاى شغلى، اختلالات اسكلتى ـ عضلانى (Musculoskeletal Disorders) موشى ودود و درنتيجه بر كيفيت زندگى شغلى افراد، در سازمان تأثير

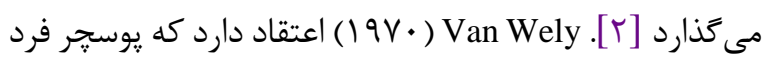
هنگام كار بلهشدت تحت تأثير طراحى ايستخاه كار است و براساس آن تعيين مىشود؛ بلهورى كه با مطالعهُ يوسجر

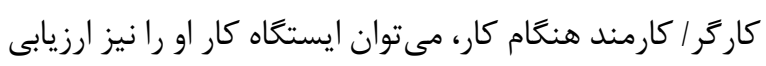

كرد [r]

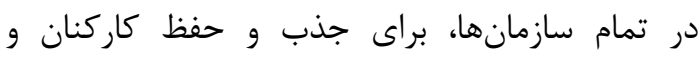

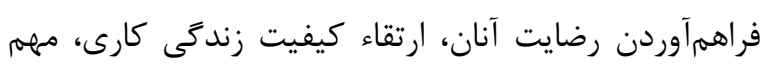
است. دراكر اعتقاد دارد كه نظام نكَهدارى منابع انسانى ابعاد مختلفى دارد و در كنار ابعاد ملموس، ويزگى هاى عاطفى و احساسى ناملموسى نيز وجود دارد كه در هر سازمان يا جامعه دئ داردئ به نحوى نمايان مىشود. عواملى كه در حفظ كاركنان تأثير مى عذارند، بيشتر مرتبط با تندرستى، اقدامات ايمنى و و

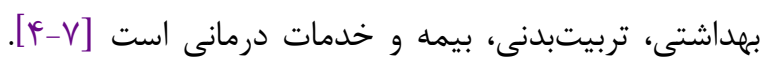

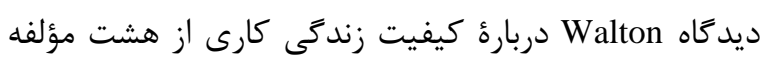
تشكيل مىشود كه عبارتاند از: يرداخت منصفانه و كافى دئ زئ (The payment of fair and adequate) بهداشتى (Safe and healthy working environment)، تأمين فرصت رشد و امنيت مداوم ( Providing ،(opportunities for growth and continuous security قانون گرايى در سازمان (Legalism in the organization)، وابستخى اجتماعى زندگى كارى (Wocial dependence of

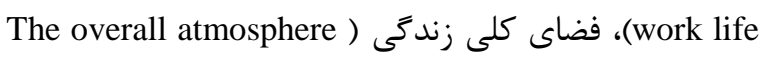

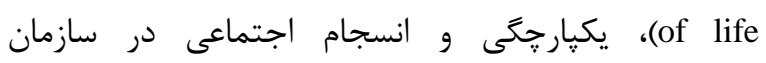
،(Integration and social cohesion in the organization) توسعة قابليتهاى انسانى (Development of human ) .[^] (capabilities بررسىها نشان مىدهند كه رايجترين نواحى درد، ناحئ

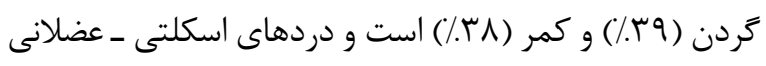
تأثيراتى منفى بر كيفيت زندگى شغلى معلمان دارد [9] (9). در

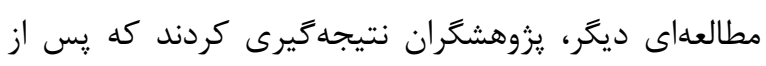

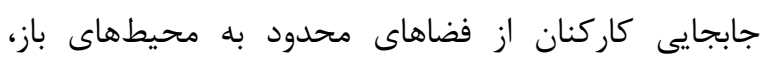
سردردها و دردهاى يشت آنان بسيار كاهش يافت؛ اما تفاوت 
raD نفر كاركنان بخشهاى ادارى كه شامل مديران،

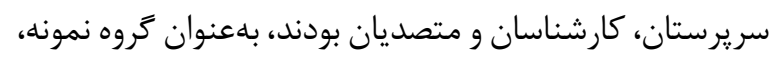

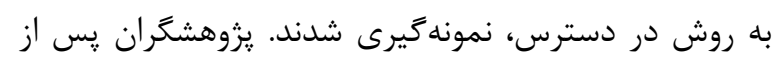

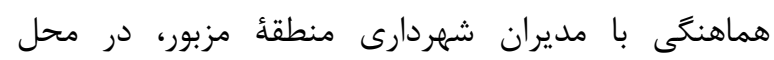

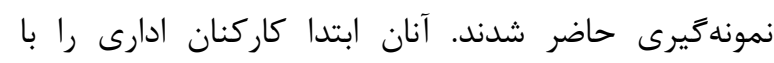

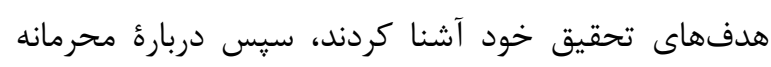
بودن اطلاعات كردآورى شده توضيح دادند. زمانى كه كه كار كنان

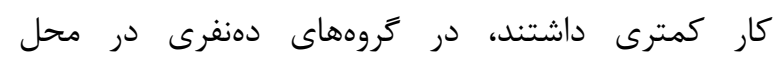

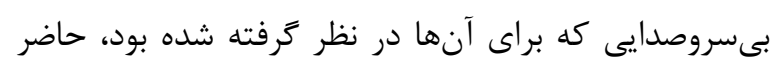

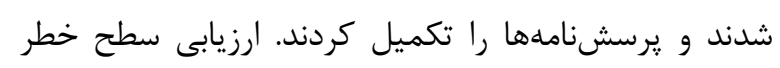

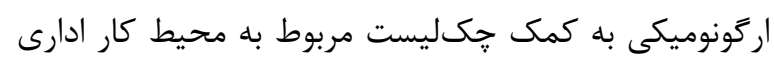

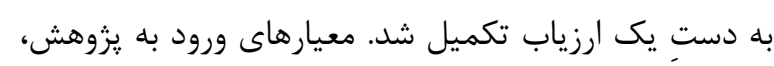

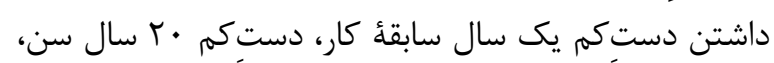

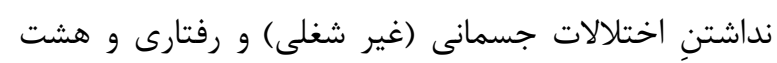

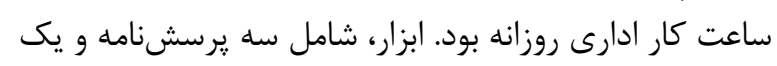

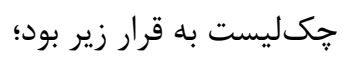
يرسشنامة اطلاعات فردى ـ شغلى

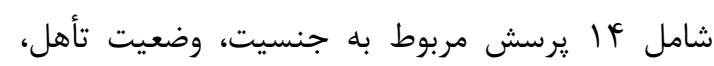

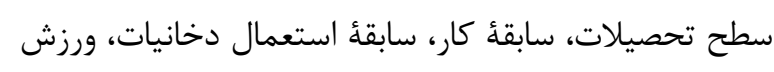

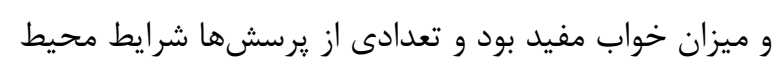

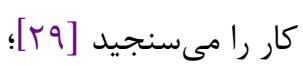

\section{يرسشنامة اختلالات اسكلتى ـ عضلانى نورديك إنى}

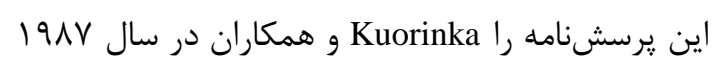

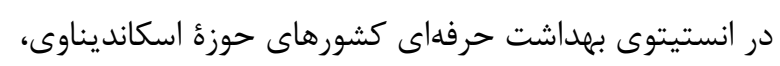

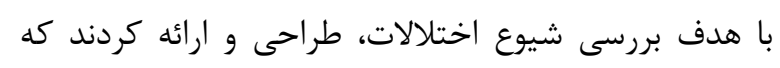

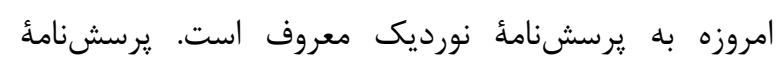

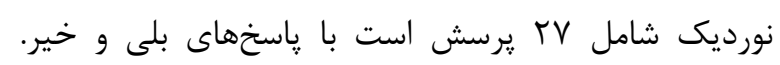

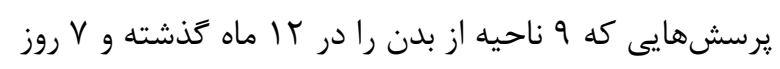

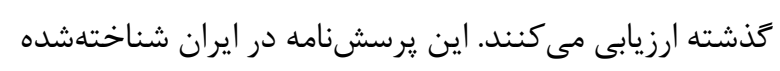

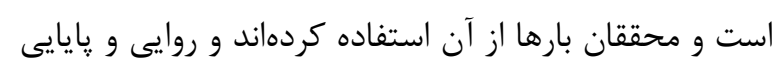
آن تأييد شده است مجفان بارها آنّ]؛

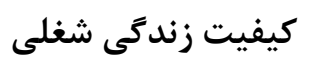

(9VY) Walton

شغلى كاركنان، اين يرسشنامه را ساخته است كه هشت

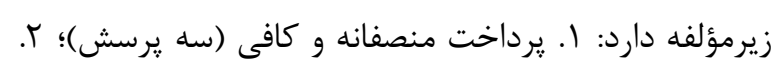

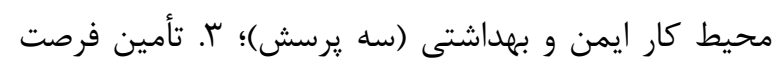

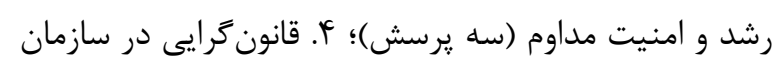

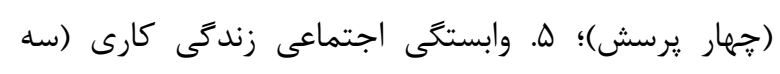

مداخلات فردى، همجون تغيير سبك زندكى و مداخلات

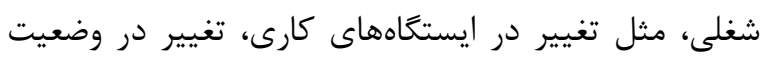

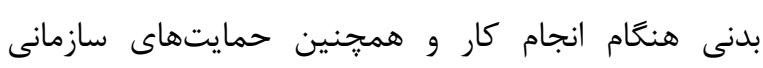

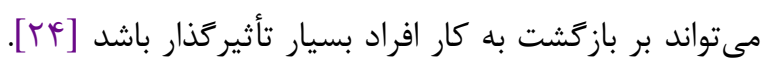
بعضى از تحقيقات نشان مى دهد كه ارتباط معنادارى بين سن،

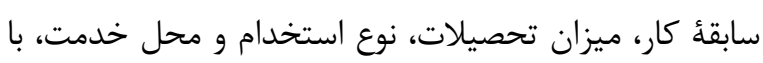

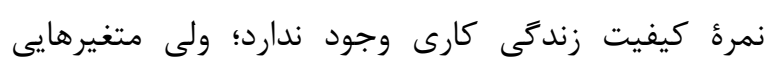

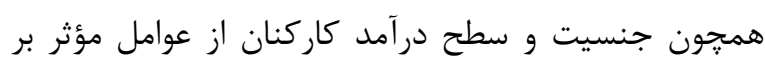

كيفيت زندگى كارى به شمار مى آيند [Tهان.

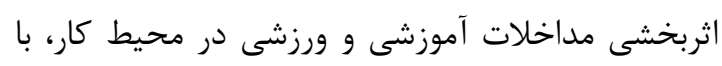

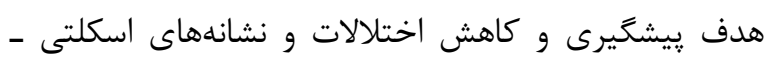

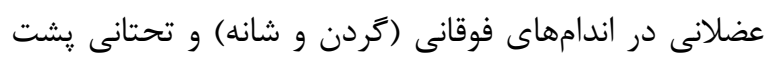

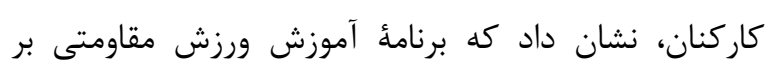

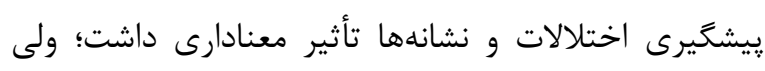

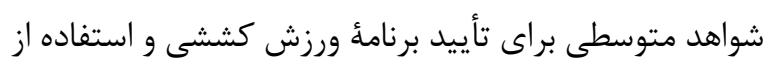

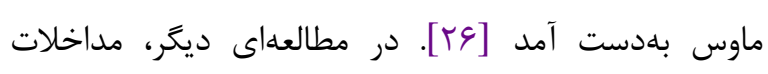

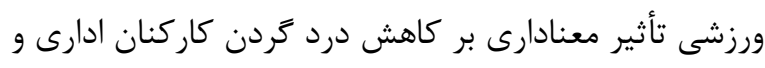
بخش مديريت و اثر متوسطى بر قسمت تحتانى يشت كارئ كاركنان

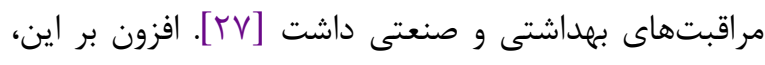

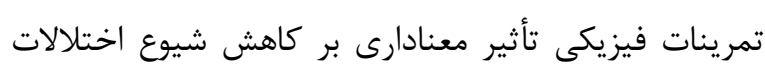

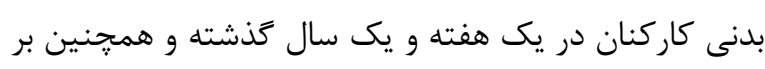

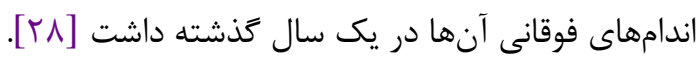
اين تحقيق با هدف ارزيابى اركونوميكى ايستخاههاى كارى إنى

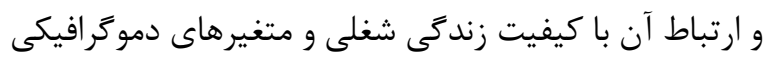

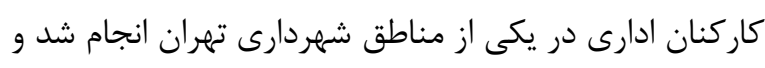

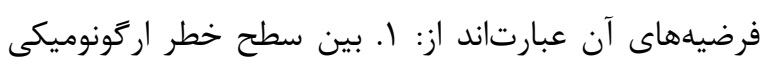

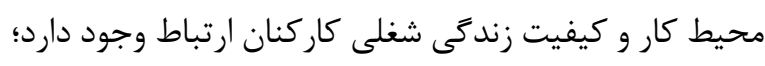

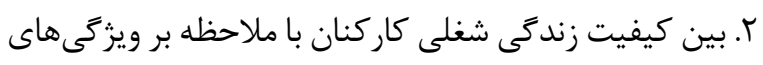

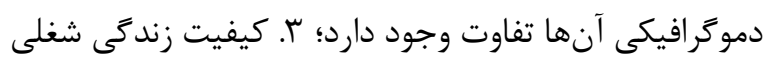

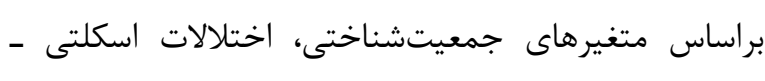

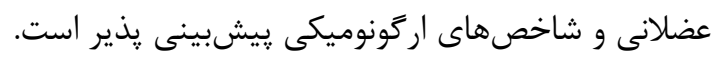
روش كار

\section{جمع آورى نمونهها و جامعه مطالعه}

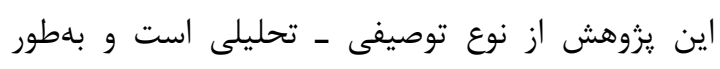

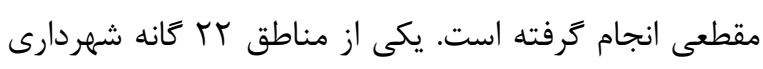

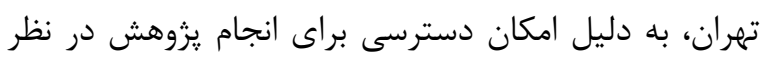

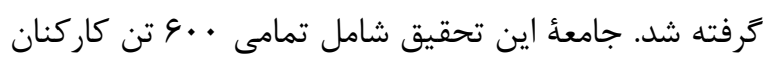

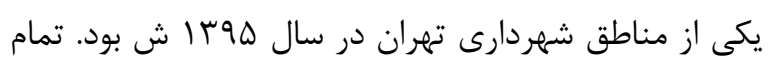


يوسجر كارى (يوسجر نواحى مختلف درگير هنگام كار كردن در حالت نشسته)، وسايل و تجهيزات (شامل ابعاد ميز و

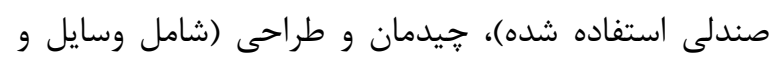
تجهيزات واقعشده در ايستخاه كارى)، شرايط محيطى (نور،

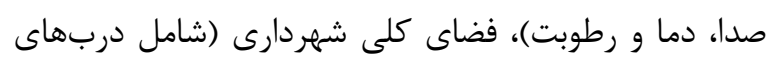
ورود و خروج و آبخورى) و كاربست ارگونومى (آموزش، دمان

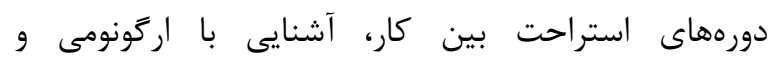

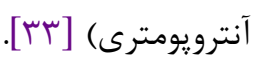

\section{تجزيه و تحليل دادهها}

براى تجزيهوتحليل دادهها از آمار توصيفى (جداول توزيع فراوانى و درصد) و استنباطى (آزمونهاى t و و ركرسيون

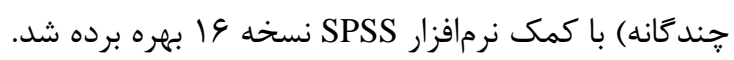

\section{يافته ها}

يافتهاى توصيفى مربوط به متغيرهاى دموگرافيكى در جدول شماره ا ديده مىشود، ضمناً ميانگين و انحراف معيار

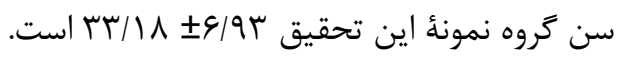

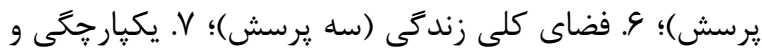

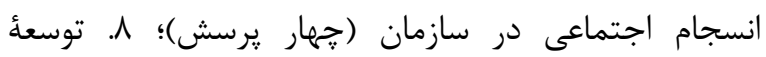
قابليتهاى انسانى (جهار يرسش ) و براساس طيف ليكرت از "اخيلى كمه تا اخيلى زياد" تنظيم شده است. به ززينه

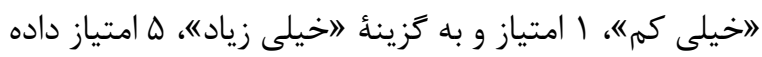
مىشود. براى امتيازبندى، نمره بالاى هر مؤلفه، تعيين كننده

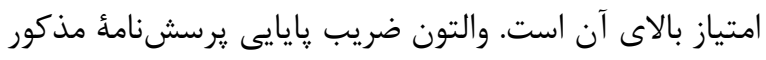

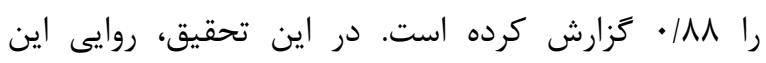
يرسشنامه را جند تن از روانشناسان و متخصصان بررسى و

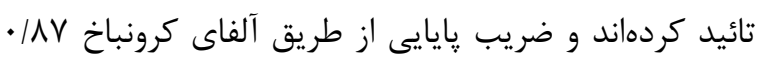

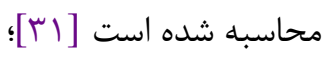

\section{جكليست ارزيابى اركونوميكى محيط كار ادارى إنى} اين جكليست بركرفته از فرم اصلى OSHA است كه يس از بررسى روايى محتوايى آن متخصصان و كارشناسان مربوط، براى ارزيابى ايستخاههاى كارى كاركنان بانكى تهيه

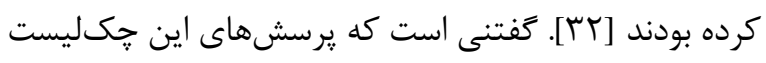
براى گروه نمونه اين تحقيق (كاركنان ادارى شاغل در برد شهردارى) تنظيم شده است. آيتمهاى آن عبارتاند ازئ

جدول ا. يافتهاى توصيفى مربوط به متغيرهاى دموكر افيكى

\begin{tabular}{|c|c|c|}
\hline درصد & تروهبندى & مشخصات دموكَرافيكى \\
\hline$\Delta q / q$ & زن - ت ان & \multirow{2}{*}{ جنسيت } \\
\hline $\mathrm{Fr/l}$ & 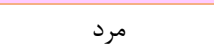 & \\
\hline$\wedge r / V$ & دانشكاهى & \multirow{2}{*}{ تحصيلات } \\
\hline $1 \varepsilon / \pi$ & غير دانشعاهى & \\
\hline $99 / 1$ & متأهل & \multirow{2}{*}{ شرايط تأهل } \\
\hline$r \cdot / r$ & مجرد & \\
\hline $4 q / r$ & وزن كم و نرمال & \multirow{2}{*}{ 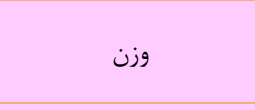 } \\
\hline$\Delta \cdot / \Lambda$ & اضافه وزن & \\
\hline DI & داراى تمرين ورزشى & \multirow{2}{*}{ ورزش در طول هفته } \\
\hline$p q$ & بدون تمرين ورزشى & \\
\hline $4 \cdot / r$ & ^ ساعت و كمتر & \multirow{2}{*}{ ميزان ساعت كارى } \\
\hline$r q / \wedge$ & بيش از ^ ساعت & \\
\hline FF/S & كمتر از ه سال & \multirow{3}{*}{ سابقه كار } \\
\hline Fr/T & ه تا ها سال & \\
\hline $\mid r / T$ & بيشتر از ها سال & \\
\hline$F r / F$ & كمتر از V ساعت & \multirow{3}{*}{ ميزان خواب } \\
\hline$\Delta 1 / 1$ & بين V تا ^ ساعت & \\
\hline $9 / 0$ & بيشتر از 1 ساعت & \\
\hline
\end{tabular}

ارتباط و شاخص يوسجر كارى، كمترين ارتباط را با نمره

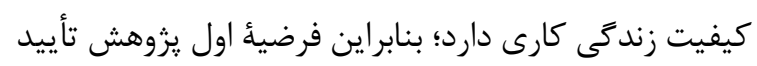
مى شود. - ميعيل
با توجه به جدول ז، بين تمام شاخصهاى ارگونوميكى،

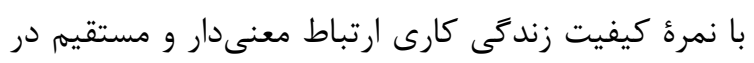
سطح ه • • • وجود دارد. شاخص كل ارگتونوميكى، بيشترين 
معنىدارى بيشتر از كاركنانى است كه در ديگر سطوح اين متغير، وضعيت خود را گزارش كردهاند. ازاينرو، فرضئُ دوم در برخى از متغيرهاى دموگرافيك تأييد مى ونودي با توجه به جدول ه، متغيرهاى سن، تحصيلات، ميزان

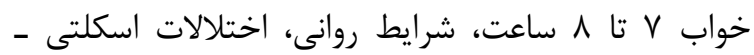

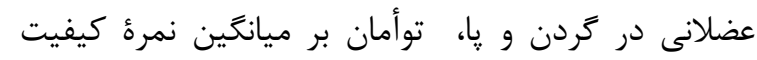

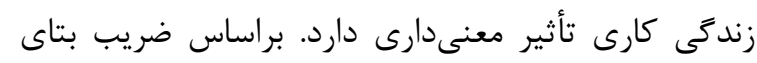

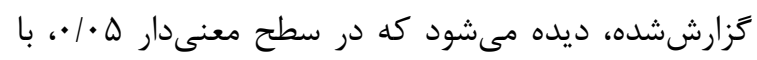

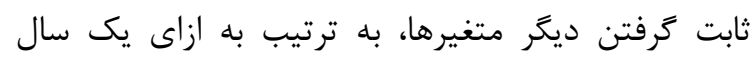

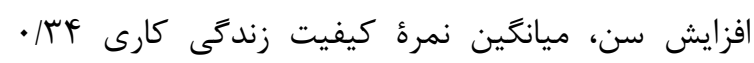

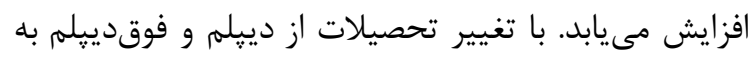

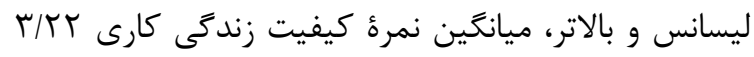

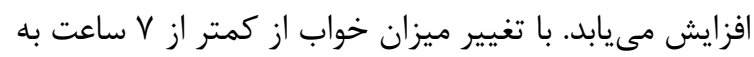

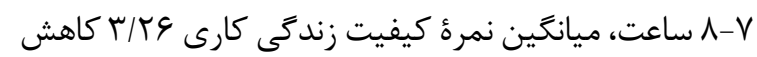
مىيابد. با تغيير وضعيت از شرايط روانى خيلى بد يا بد به مانه

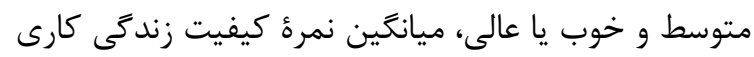

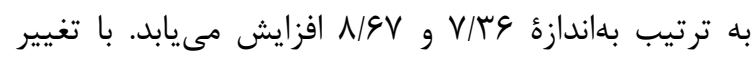

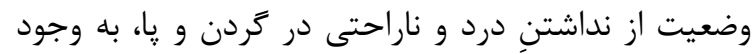

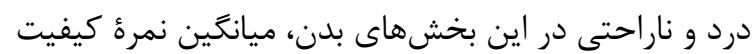
زند
همان طور كه در جدول شماره ب ديده مىشود، ميانخين

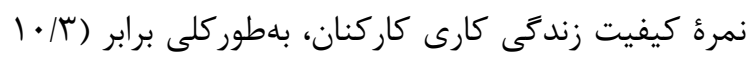
(FA/VF士

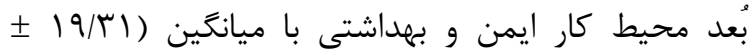

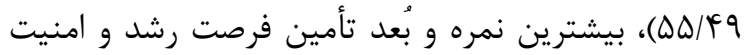

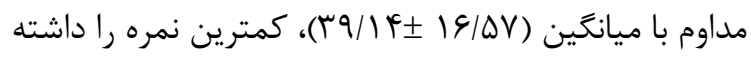
همانطور كه در جدول f أ مشاهده مىشود، تفاوت ميانگين در كيفيت زندگى كارى با ملاحظه بر متغيرهاى

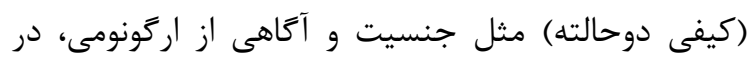

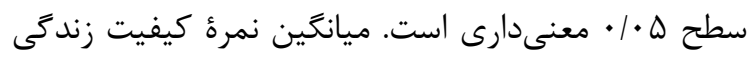

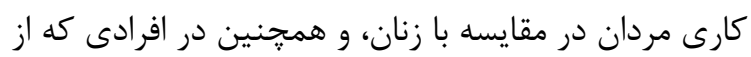

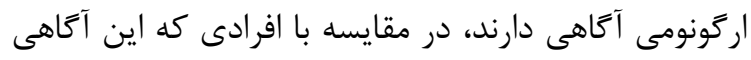

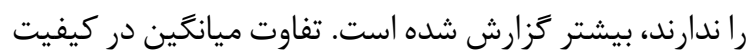

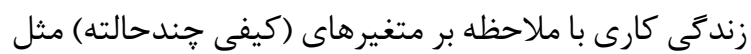

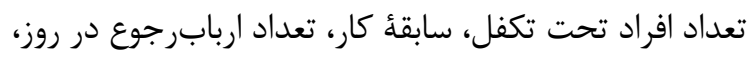
ميزان ساعات خواب، شرايط فيزيكى و روانى، در سطح هـ • • • • فقط بين متغيرهاى شرايط فيزيكى و روانى با ميانگين نمرءٔ

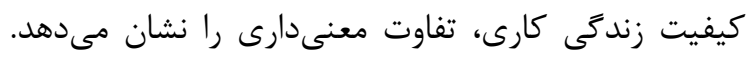

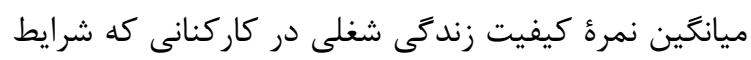

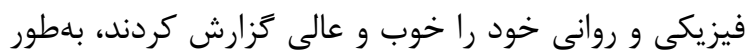

جدول ז: ارتباط بين سطح خطر اركونوميكى محيط كار با نمرة كيفيت زندگى كارى از طريق ضريب همبستكى پيبرسون

\begin{tabular}{|c|c|c|}
\hline Pقدار P P P & ضر يب همبستكى & ابعاد خطر ارَّونوميكى \\
\hline$<\bullet / .+1$ & $\cdot \pi F$. & شاخص يوسجر كارى \\
\hline$<\bullet / \bullet 1$ & $\cdot / r \Delta S$ & شاخص وسايل و تجهيزات \\
\hline$<\bullet / .+1$ & $\cdot|\pi| 9$ & شاخص קيدمان و طراحى \\
\hline$<\bullet / \bullet 1$ & - MFs & شاخص شرايط محيطى \\
\hline$<\bullet / \cdot+1$ & - MFF & شاخص فضاى كلى شهردارى \\
\hline$<\bullet / \cdot \bullet 1$ & $\cdot / T \wedge \Delta$ & شاخص كاربست اركونومى \\
\hline$<* / .+1$ & $\cdot / r \Delta V$ & شاخص كل اركونوميكى ايستكاه كار \\
\hline
\end{tabular}


جدول r. آمارههاى توصيفى مربوط به ابعاد مختلف كيفيت زندكى كارى كاركنان (N= r

\begin{tabular}{|c|c|c|}
\hline انحراف معيار & 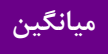 & ابعاد مختلف كيفيت زندكى كارى \\
\hline$|r / 9|$ & $F N / \Delta \Lambda$ & يرداخت منصفانه و كافى \\
\hline $19 / 41$ & $\Delta \Delta / \& q$ & محيط كار ايمن و بهداشتى \\
\hline $18 / \Delta V$ & rq//f & تأمين فرصت رشد و امنيت مداوم \\
\hline $\mid \Delta / \vee \wedge$ & $01 / \pi \varphi$ & قانونَّر ايى در سازمان \\
\hline If/rr & $r q / \Delta q$ & وابستكى اجتماعى زندكى كارى \\
\hline Ir/Ir & $f \Delta / V \Lambda$ & فضاى كلى زندَى \\
\hline $19 / v 9$ & FA/Vr & يكيار جحىى و انسجام اجتماعى در سازمان \\
\hline $1 \% / \Delta 9$ & FN/TF & توسعة قابليتهاى انسانى \\
\hline $1 . / 4$ & FA/VF & نمرهٔ كيفيت زندكى كارى (كلى) \\
\hline
\end{tabular}

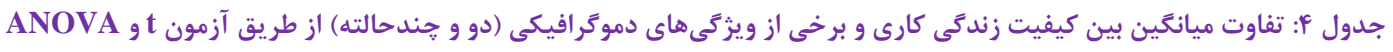

\begin{tabular}{|c|c|c|c|c|c|}
\hline Pقدار P P & انحر اف معيار & ميانكين كيفيت زندكى كارى & تعداد & 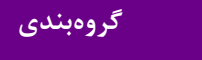 & مشخصات دموكرافيك \\
\hline \multirow{2}{*}{.$/ \cdot 1 V$} & $1 \cdot|\Delta|$ & $48 / 91$ & 11. & زن & \multirow{2}{*}{ جنسيت } \\
\hline & $9 / 97$ & $\Delta \cdot / / V$ & IfS & 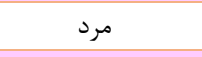 & \\
\hline \multirow{2}{*}{.1 .19} & $9 / 4 T$ & $\Delta \cdot / \Lambda \Lambda$ & $v \Delta$ & 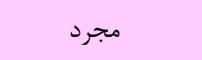 & \multirow{2}{*}{ آكاهى از ارَّونومى } \\
\hline & $1 \cdot / 4$. & $\mid N / T)$ & IVr & متأهل & \\
\hline \multirow{3}{*}{. ITr } & 1.194 & $19 / 48$ & 19 & ا نفر & \multirow{3}{*}{ تعداد افراد تحت تكفل } \\
\hline & IT/AT & FN/TT & rF & r نفر & \\
\hline & $1 \% / 99$ & $f \backslash / / Q$ & 10 & ك آنفر يا بيشتر & \\
\hline \multirow{3}{*}{$\cdot / V \Delta \Lambda$} & $9 / 1 V$ & $\Delta \cdot / T F$ & 99 & ه سال و كمتر & \multirow{3}{*}{ سابقه كار } \\
\hline & $9 / \pi 4$ & $19 / 19$ & १९ & ه D- Dال & \\
\hline & IT/AS & $4 q / 1$. & TV & بيش از ها سال & \\
\hline \multirow{3}{*}{$\cdot|V| \cdot$} & $11 / \pi 8$ & $r q / \Delta \wedge$ & $\mid$ & 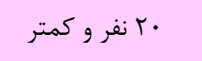 & \multirow{3}{*}{ تعداد اربابرجوع در روز } \\
\hline & $0 / 19$ & $F N / \Delta D$ & rq & 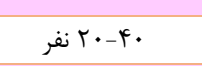 & \\
\hline & $9 / 1 \vee$ & $\Delta \cdot / 4 \varphi$ & $\forall \wedge$ & بيش از • أ نفر & \\
\hline \multirow{3}{*}{.1991} & $11 / T V$ & $4 q / r q$ & $1 \cdot 4$ & V ل ل ساعت و كمتر & \multirow{3}{*}{ ميزان ساعات خواب } \\
\hline & $9 / \wedge F$ & $\mid F N / T)$ & ITS & 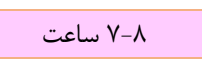 & \\
\hline & $\Delta / \wedge r$ & $49 / 94$ & 19 & بيش از ^ ساعت & \\
\hline \multirow{3}{*}{$<\cdot|\cdot \cdot|$} & $\Lambda / r V$ & FVITT & r & خيلى بد و بد & \multirow{3}{*}{ شرايط فيزيكى } \\
\hline & $1 \cdot / 1 T$ & FE/QT & 119 & متوسط & \\
\hline & $9 / \cdot \Delta$ & $\Delta r / \Delta Q$ & 1.9 & خوب و عالى & \\
\hline \multirow{3}{*}{$<\cdot|\cdot \cdot|$} & $11 / \Delta \Delta$ & $r / / 90$ & r. & خيلى بد و بد & \multirow{3}{*}{ شرايط روانى } \\
\hline & $9 / 14$ & $F V / T I$ & 99 & متوسط & \\
\hline & N/TF & $\Delta \Gamma / \cdot V$ & 119 & خوب و عالى & \\
\hline
\end{tabular}




\begin{tabular}{|c|c|c|c|c|c|c|}
\hline \multirow{2}{*}{$\begin{array}{l}\text { P-value } \\
<\bullet|+\bullet|\end{array}$} & \multirow{2}{*}{$\begin{array}{c}T \\
F / f V\end{array}$} & \multirow{2}{*}{ فاصلة اطمينان } & \multicolumn{2}{|c|}{ انحراف معيار } & \multirow{2}{*}{ ضريب بتا } & \multirow{2}{*}{ متغيرهاى بيشبينى كننده } \\
\hline & & & Tr/QT & $9 / \cdot r$ & & \\
\hline.$/ \cdot Y V$ & $r / T r$ & .194 &.$/ .4$ & $\cdot 110$ & $\cdot / \mu F$ & سن \\
\hline \multirow[t]{2}{*}{$.1+F V$} & $r / .$. & $9 / 4 \mid$ & .1 .4 & $1 / 91$ & T/T & تحصيلات \\
\hline & & & & & & ميزان خواب \\
\hline .1 .10 & $-t / \& Q$ &.$- \mid q \mu$ & $-\Delta / \Lambda \Lambda$ & ITr & (T/Te & 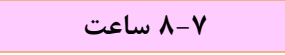 \\
\hline $.19 \mathrm{pr}$ & $-\cdot / 49$ & $\varphi / v$ & $-9 / \Delta V$ & $r / 99$ & $-1 / \pi \Delta$ & بيش از ^ ساعت \\
\hline \multirow[t]{2}{*}{. /rrq } & $-1 / 11$ & $1 / \cdot 1$ & $-\varphi / \cdot \Delta$ & $1 / r \Lambda$ & $-1 / Q T$ & دورههاى روانشناسى \\
\hline & & & & & & سابقهُ كار \\
\hline.$/ 999$ & $-\cdot \cdot / \cdot 1$ & r/Ve & $-r / V \wedge$ & $1 / 91$ & $-\cdot / \cdot 1$ & ه-هال \\
\hline.$/ 19 r$ & $-1 / 41$ & $r / \cdot 1$ & $-9 / 91$ & $r / \cdot r$ & $-4 / 90$ & بيش از ها سال \\
\hline \multirow[t]{2}{*}{.$/ \cdot v r$} & $-1 / 11$ & $\cdot / \pi$ & $-\Delta / T$ & $1 / r V$ & $-r / 4 \Lambda$ & ساعت كار \\
\hline & & & & & & شرايط فيزيكى \\
\hline . IFVF & $-\cdot / V T$ & $r / \Delta \varphi$ & $-\infty / 4 q$ & $r / \cdot \varphi$ & $-1 / 48$ & متوسط \\
\hline \multirow[t]{2}{*}{./IFT } & $1 / \mathbb{F V}$ & V/qr & $-1 / 10$ & $r / \mu \cdot$ & r/rq & خوب و عالى \\
\hline & & & & & & شرايط روانى \\
\hline.$/ . r$ & $r / T \cdot$ & $11 / 9$. & $r / \Lambda)$ & $r / \mu \cdot$ & V/rG & متوسط \\
\hline$\cdot 1 \cdot .1$ & $r / F F$ & $1 \pi / 99$ & ए/९q & T/QT & N/9V & خوب و عالى \\
\hline .1 .09 & $-T / V \varphi$ & $-1 / \pi$ & $-V / T \Delta$ & I/QT & $-F / T r$ & 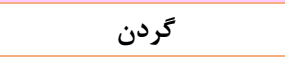 \\
\hline ./ & $-1 / \cdot f$ & $r / \cdot F$ & $-8 / 9$ & $r / 19$ & $-T / T \Lambda$ & آرنج \\
\hline $.1 . .1$ & $-r / T F$ & $-r / r$. & $-1 \% / 9$. & $r|9|$ & $-\Lambda / \uparrow \Delta$ & يا \\
\hline$\cdot / r \cdot 9$ & $1 / \cdot r$ &.$/ 1 T$ & $-\cdot / \cdot r$ & $\cdot / \cdot 4$ &.$/ \cdot F$ & يوسجر \\
\hline . ITTV & $1 / T 1$ & $\cdot / 10$ & $-\cdot / \cdot r$ & $\cdot / \cdot \Delta$ & $.1 \cdot 9$ & طراحى \\
\hline - /TAV & $-1 / 1 f$ & $\cdot / \cdot r$ & $-\cdot / 14$ & $\cdot / \cdot f$ & $-\cdot / \cdot f$ & محيطى \\
\hline
\end{tabular}

مناطق تهران، بيشترين شيوع اختلالات اسكلتى ـ عضلانى،

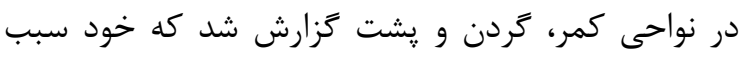
كاهش كيفيت زندگى شغلى كاركنان شده است. دلايل

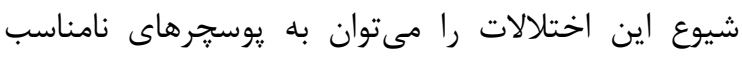
كاركنان در بخش ادارى مربوط دانست.

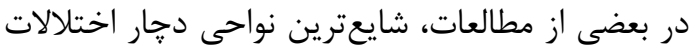

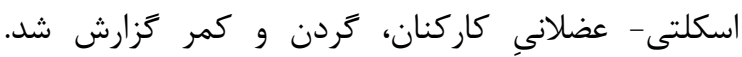

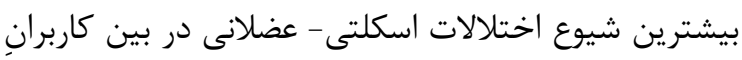
كامييوتر، در ناحئ كردن، شانه، كمر و يشت بود كه با نتايج

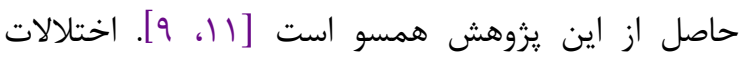

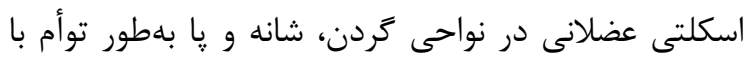
ميانگين نمرء كيفيت زندكى شغلى كاركنان شهردارى ارتباط معنىدارى دارند. با ثابت كرفتن ديكر متغيرها، به

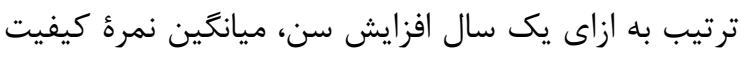

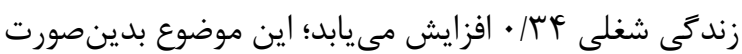

بحث و نتيجه كيرى بين رعايت اصول اركونوميكى و وجود درد در بخشهاى مختلف بدن ارتباط منفى و معنادارى وجود دارد. حنانجه

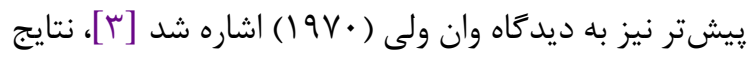

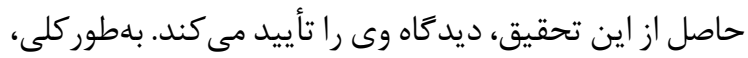

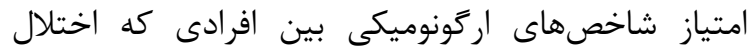

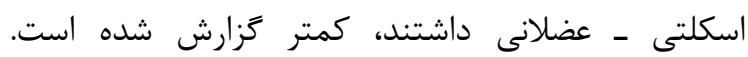

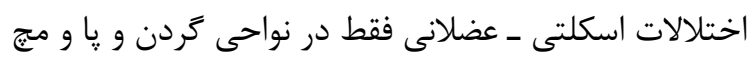
ها، بر كيفيت كلى زندگى شغلى كارمندان ادارى (با ميانكين

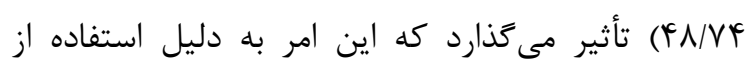

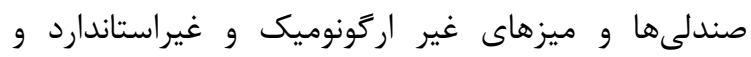

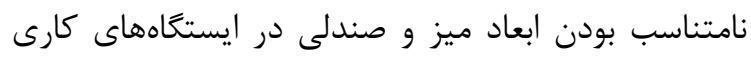

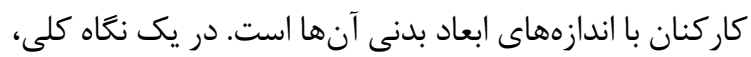

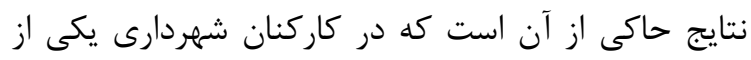


كاركنان با شرايط روانى محيط كار، باركارى و روابط با

$$
\text { همكاران خود است. }
$$

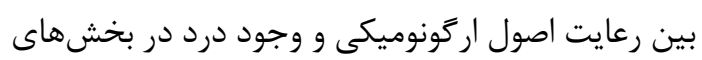

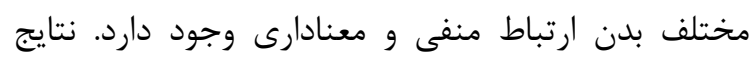

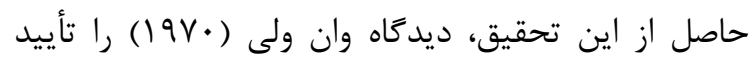

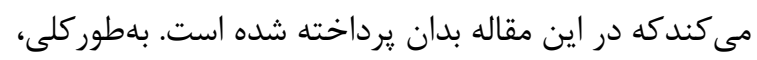

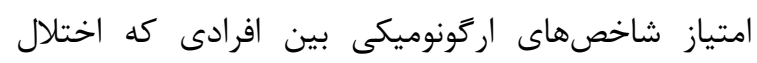

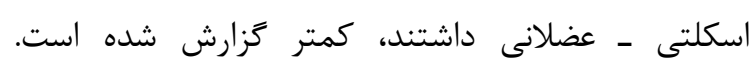

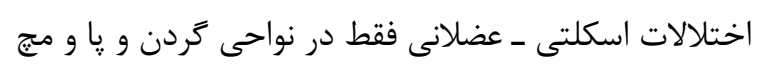

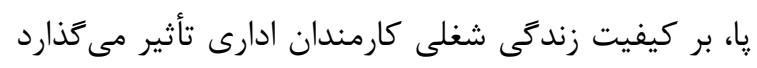

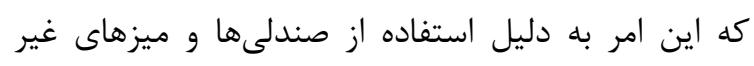

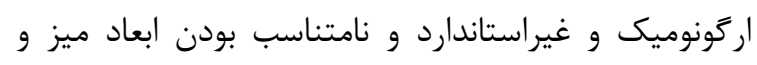
صندلى در ايستگاههاى كارى كاركنان با اندازههاى ابعاد

$$
\text { بدنى آنهاست. }
$$

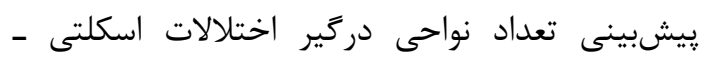

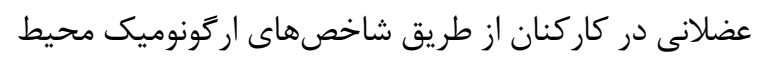
كار ادارى امكانيذير است. بدين ترتيب كان كه با با افزايش امتياز

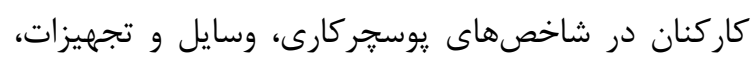
شرايط محيطى و فضاى كلى شهردارى، تعداد نواحى دركير تونير

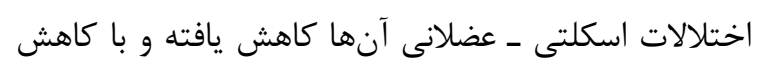

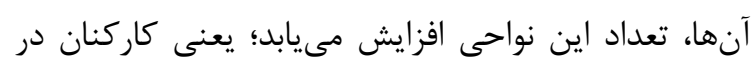

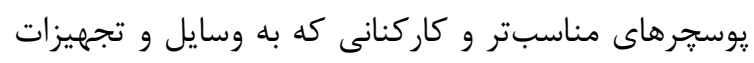

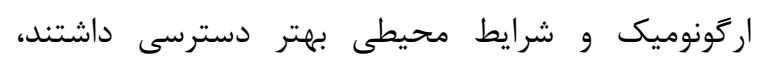

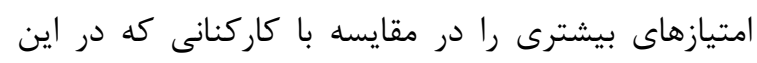
شاخصها ضعيف بودند، كسب كردند.

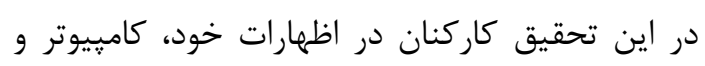

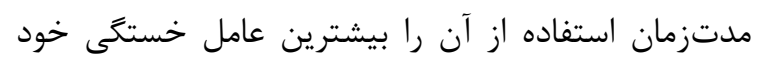

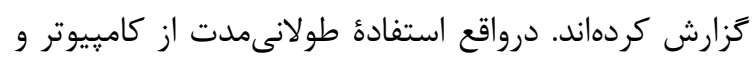

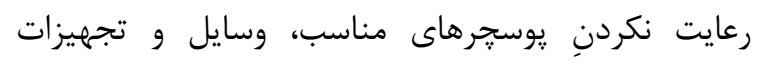

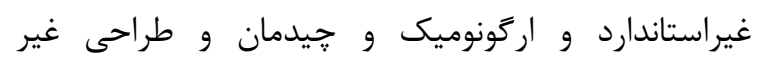

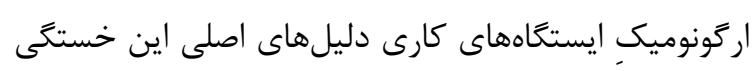

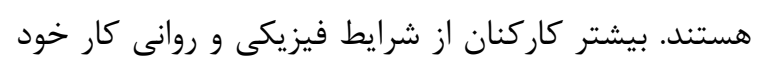

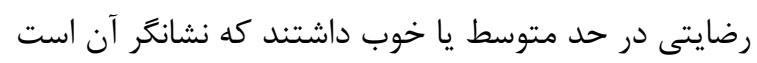

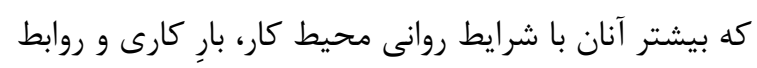

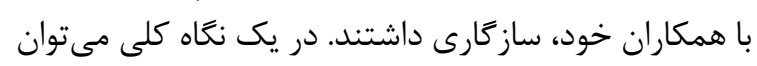
كفت كه استاتيك و تكرارى بودن كار دران دران محيط ادارى دارى

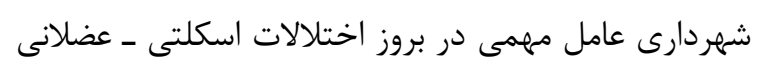

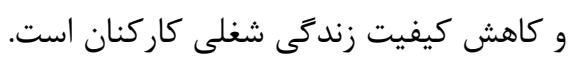

توجيه يذير است كه افراد با سن بالاتر، قراردادهاى كارى

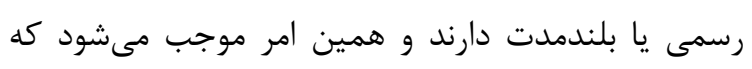

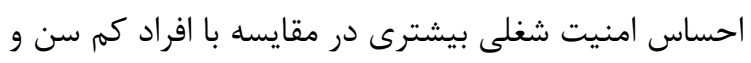

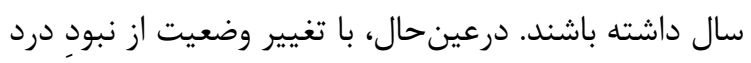

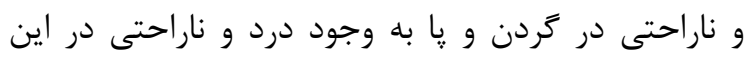

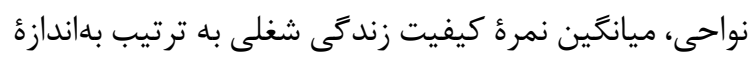

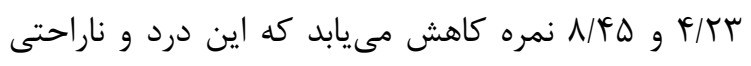

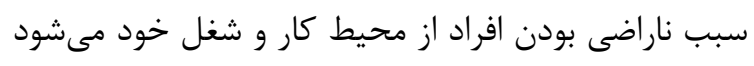
و درنتيجه به كاهش كيفيت زندكى شغلى كاركنان منجر

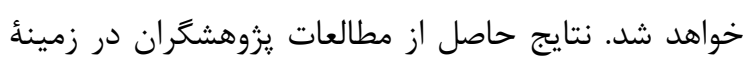

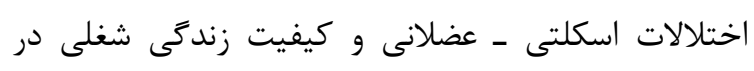

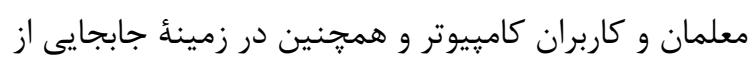

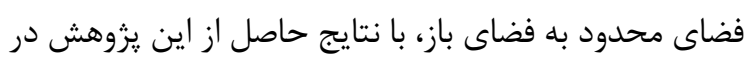

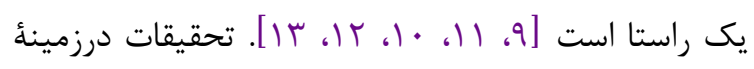

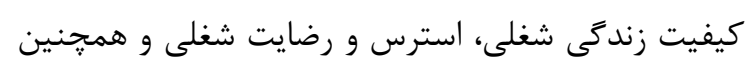

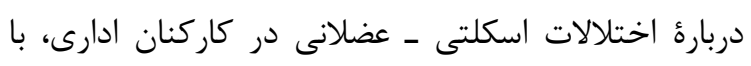

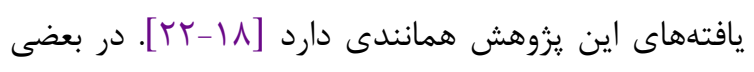

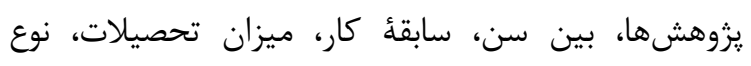

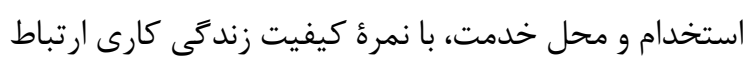

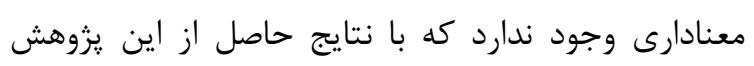

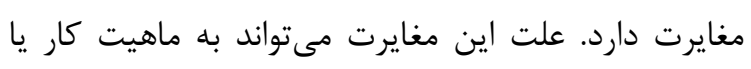

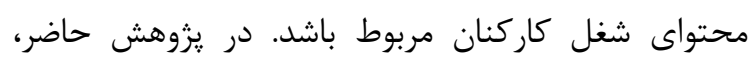

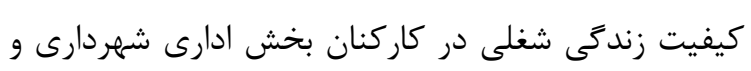

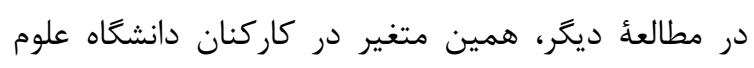

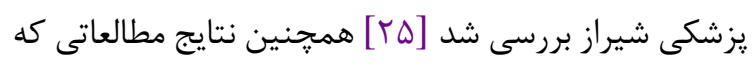

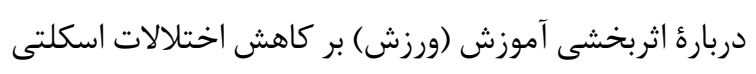

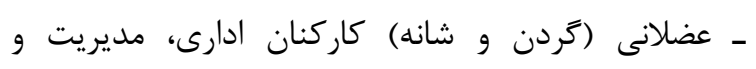

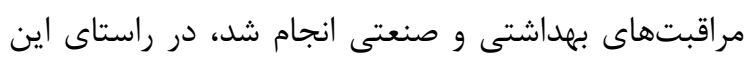

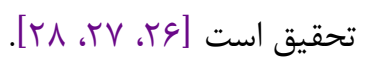
در اين تحقيق، كاركنان در اظهارات خوات خود، بيشتر

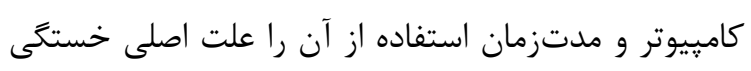

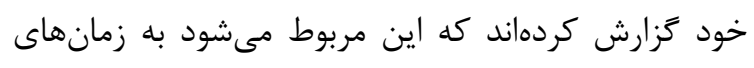

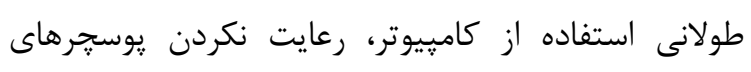

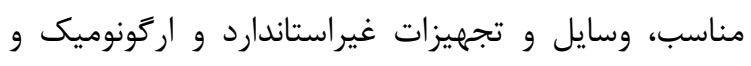
جيدمان و طراحى غير ارگتونوميك ايستخاههاى كارى. بيشتر

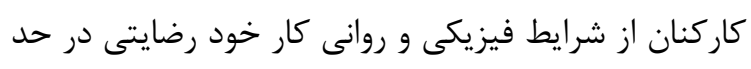
متوسط يا خوب داشتند كه اين به معناى سازكارى اين اين 


$$
\begin{aligned}
& \text { و روانى، علاوه بر ارائٔ خدمات بهتر به شهروندان، خود نيز } \\
& \text { كمتر دجار آسيب شوند. } \\
& \text { تقدير و تشكر } \\
& \text { نويسندگان مراتب تشكر و قدردانى خود را از مساعدت } \\
& \text { و همكارى مسئولين و كاركنان شهردارى تهران اعلام } \\
& \text { مى كنند. } \\
& \text { تعارض منافع } \\
& \text { بين نويسندكان هيجزونه تعارضى در منافع وجود ندارد. }
\end{aligned}
$$

\section{References}

1. Rupesh K. Ergonomic evaluation and design of tools in cleaning occupations (Doctoral dissertation, Doctoral thesis]. Sweden: Department of human work sciences-University of technology).

2. Yousefi HA. Ergonomic hazard in one of the industrial companies. Proceeding of the $1 \mathrm{St}$ National Conference of Occupational Health and Safety Management on Tehran, Iran 2004 Dec; 16-17[Persian]

3. van Wely P. Design and disease. Appl Ergon. 1970 Dec;1(5):262-9. https://doi.org/10.1016/0003-6870(70)90075-X PMID: 15676337

4. Islam MS. Quality of work life: an insight of causes of attrition in insurance sector in India. 2011

5. Monograph on the internet. Frequently Asked Questions [Internet]. 2005. Available from: http://WWW.hhs.gov

6. Sandrich K. Putting the emphasis employees as an award- winning employer, Bap test Health Care has distant memories of the work force shortage. U S A: Trustee; 2003.

7. Drucker PF. Management challenges for the $21 \mathrm{st}$ century. Routledge; 2007.

8. Roodaki M. Dynamic analysis of the quality of work life. Research plan of work and social supply organization Quoted from www karafaringow ir. 2008.

9. Karakaya İÇ, Karakaya MG, Tunç E, Kıhtır M. Musculoskeletal problems and quality of life of elementary school teachers. Int J Occup Saf Ergon. 2015;21(3):344-50. https://doi.org/10.1080/10803548.2015.1035921 PMID:26327160

10. Helland M, Horgen G, Kvikstad TM, Garthus T, Aarås A. Will musculoskeletal and visual stress
اين تحقيق فقط در يكى از مناطق r r Fانه شهردارى

تهران انجام شد و كنترل نداشتن بر وضعيت روانى كاركنان

در هنگام تكميل يرسشنامهها از محدوديتهاى اين تحقيق

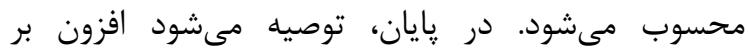

مهياكردن محيط كارى منطبق با اصول ارگونوميك، ضرورى

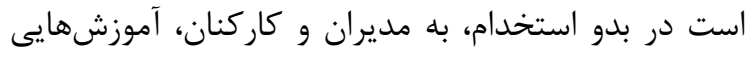

درزمينهُ رعايت اصول ارگونوميك داده شود تا آنها بهديه

اهميت اين امر آكاه باشند و بتوانند با حفظ سلامت جسمانى رئى

change when Visual Display Unit (VDU) operators move from small offices to an ergonomically optimized office landscape? Appl Ergon. $2011 \quad$ Nov;42(6):839-45. https://doi.org/10.1016/j.apergo.2011.01.007 PMID:21338981

11. Akrouf QA, Crawford JO, Al-Shatti AS, Kamel MI. Musculoskeletal disorders among bank office workers in Kuwait. East Mediterr Health J. 2010;16(1):94-100. PMID: 20214165

12. Mosadeghrad AM, Ferlie E, Rosenberg D. A study of relationship between job stress, quality of working life and turnover intention among hospital employees. Health Serv Manage Res. 2011

Nov;24(4):170-81. https://doi.org/10.1258/hsmr.2011.011009 PMID:22040944

13. Schmidt DR, Dantas RA. Quality of work life and work-related musculoskeletal disorders among nursing professionals. Acta Paul Enferm. 2012;25(5):701-7.

https://doi.org/10.1590/S010321002012000500009.

14. Wagenaar AF, Taris TW, Houtman IL, van den Bossche S, Smulders P, Kompier MA. Labour contracts in the European Union, 2000-2005: differences among demographic groups and implications for the quality of working life and work satisfaction. Eur J Work Organ Psychol. 2012;21(2):169-94.

https://doi.org/10.1080/1359432X.2010.548121.

15. Natarajan C, Kiruthika V. Factors contributing quality of work life of employees in select Magnesite Companies: an empirical study. Int J Manag. 2013;4:188-94.

16. Almalki MJ, Fitzgerald G, Clark M. Quality of work life among primary health care nurses in the Jazan region, Saudi Arabia: a cross-sectional study. Hum Resour Health. 2012 Sep;10(1):30. https://doi.org/10.1186/1478-4491-10-30 PMID:22971150 
17. Tüzün EH. Quality of life in chronic musculoskeletal pain. Best Pract Res Clin Rheumatol. $2007 \quad$ Jun;21(3):567-79. https://doi.org/10.1016/j.berh.2007.03.001 PMID:17603000

18. Goudarznand-Chegini M, Mirdoozandeh SG. Relationship between quality of work-life and job satisfaction of the employees in public hospitals in Rasht [Persian]. Zahedan J Res Med Sci. 2012;14(2):108-11.

19. Falahi M. The relationship between quality of work life and job control and stress with the number, severity, prevalence of physical illness in the chemical industry employees Gulf. Islamic Azad University of Marvdasht; 2010.

20. Maleki Z, Alafi T, Mobasheri F. Assessing prevalence of musculoskeletal disorders and some Ergonomic and demographic factors in employees Fasa University of Medical Sciences in 2015. The 2nd International Iranian Ergonomics Conference in Shiraz, Iran.2016 October; 19-21.

21. Faraji M, Akashe S, Akafi N, Nazari A. Assessing Ergonomic factors and its relation with musculoskeletal disorders in administrative units of Mobarake Steel Complex. The 2nd International Iranian Ergonomics Conference in Shiraz, Iran 2016 October; 19-21. [Persian]

22. Meshkati R, Meshkati H. Zare zade F. Assessing the ergonomic status of reception staff workstation of social security hospitals. The 2nd International Iranian Ergonomics Conference in Shiraz, Iran. 2016 October; 19-21. [Persian]

23. Mououdi N, Shahpuri R, Shukrolahi A. Ergonomically adjustable laptop desk designed based on anthropometric data of students of Mazandaran University of Medical Sciences Aged 20 to 30 Year. The 2nd International Iranian Ergonomics Conference in Shiraz, Iran. 2016October; 19-21. [Persian]

24. Mazlomi A, Norolahi M. Identifying factors affecting the return-to-work of National Iranian Oil Company administrative staff with a history of low back pain in Kharg Island.The 2nd International Iranian Ergonomics Conference in Shiraz, Iran. 2016 October; 19-21. [Persian]

25. Choobineh A, Daneshmandi H, Parand M, Ghobadi R, Haghayegh A, Zare F. The survey of quality of work life and determination of its related factors in Shiraz University of Medical Sciences staff.. J Econ. 2013;1(2):56-62.
26. Van Eerd D, Munhall C, Irvin E, Rempel D, Brewer S, van der Beek AJ et al. Effectiveness of workplace interventions in the prevention of upper extremity musculoskeletal disorders and symptoms: an update of the evidence. Occup Environ Med. 2016 Jan;73(1):62-70. https://doi.org/10.1136/oemed-2015-102992 PMID:26552695

27. Serra MV, Camargo PR, Zaia JE, Tonello MG, Quemelo PR. Effects of physical exercise on musculoskeletal disorders, stress and quality of life in workers. Int J Occup Saf Ergon. 2016:1-6. PMID:27690286

28. Coury HJ, Moreira RF, Dias NB. Evaluation of the effectiveness of workplace exercise in controlling neck, shoulder and low back pain: A systematic review. Braz J Phys Ther. 2009;13(6):461-79.

https://doi.org/10.1590/S1413355520090006000 $\underline{02}$.

29. Bahreyni M. Check ergonomic workstations and its relationship with musculoskeletal disorders and job stress branches of Bank Sepah in Tehran. Master's Thesis, School of Health, Safety and Environment Shahid Beheshti University of Medical Sciences 2014

30. Kuorinka I, Jonsson B, Kilbom A, Vinterberg H, Biering-Sørensen F, Andersson $G$ et al. Standardised Nordic questionnaires for the analysis of musculoskeletal symptoms. Appl Ergon. 1987;18(3):233-7. https://doi.org/10.1016/0003-6870(87)90010-X PMID:15676628

31. Rahimi H, Rajaeipour S, SALIMI G. A study on the quality of work life of faculty members of Isfahan public universities. JSR. 2007;15;1(12):41-54.

32. Shahnaz TY, Reza KJ, Amir K, Maryam B. Relationship between ergonomic workstations with musculoskeletal disorders and job stress among staff of Bank in Tehran city. In: International Conference on Applied Human Factors and Ergonomics. Springer; 2017. p. 37887.

33. Cohen AL. Elements of ergonomics programs: a primer based on workplace evaluations of musculoskeletal disorders. DIANE Publishing; 1997. 